\title{
Place Attachment in a Concentration Camp: Bergen-Belsen
}

\author{
Heléna Huhák
}

Research Centre for the Humanities

bubak.helena@gmail.com

In this paper, I examine ego-documents created by two Hungarian deportees regarding the Bergen-Belsen concertation camp: Margit Holländer's diary and Magda Székely's letters to her father, Károly Székely. Holländer's diary sheds light on two periods of Bergen-Belsen. The letters offer insights into experiences in two different parts of the camp at the same time. These sources include details about the everyday lives, thoughts, perceptions, and feelings of the inmates in the most extreme space of persecution. I argue that, with its focus on the attachment to place, by which I mean the emotional bond between person and place (an important concept in environmental psychology), Holländer's diary reveals how she reflected on the different spaces in the camp and how her emotions regarding the physical and natural environment shifted depending on the situations of camp life. Magda Székely's letters to her father reveal how the different sectors of the camp influenced the emotional bonds between father and daughter. I also argue that the attachments that these individuals seem to show to some of the sectors of the camp suggest that there were emotionally "positive places" in an otherwise negative environment. The illegal world of the camp, the secret act of letter writing, meetings in the "positive places," and the exchange of goods on the black market are all indications of the very limited freedom of space usage, which continued after the liberation of the camp.

Keywords: Hungarian Holocaust, Nazi concentration camp, Bergen-Belsen, egodocuments, place attachment, emotional history

Margit Holländer had a pleasant surprise at the third stop of her "lager journey" in the Salzwedel concentration camp (after Auschwitz and Bergen-Belsen). She wrote about this experience in her diary: "[...] I was taken along with many others to block no. 2. I could not believe my eyes. This cannot be true. A real desk, chairs, wooden bunk beds covered with blankets. Auschwitz, Bergen-Belsen! Heaven after hell. I tried the chairs right away. It was so good to sit on them after four months, considering that I have not even seen any chairs so far, only

1 I borrow this phrase from the title of her published diary: Holländer, Lágerutazás. 
from afar, in the rooms of the barracks leader. Everything seemed more humane here." 2

The furnishings in the barracks of the concentration camps were minimal. The interiors were dark and had little more than three-story bunks. Holländer, who was drifting among places completely unsuitable for housing humans for months, felt as if she has regained some of her humanity at the sight of a desk and a few chairs. The diary entry cited above highlights the role of furniture as a sign of stability and the impact of the material environment and spaces on an individual's emotional wellbeing. ${ }^{3}$

In this paper, I examine ego-documents created by two Hungarian deportees who were writing on the Bergen-Belsen concertation camp: Margit Holländer's diary and Magda Székely's letters to her father, Károly Székely. These texts further an understanding of the inner world of the camp society that be more subtle and nuanced than the understanding we glean from other sources. First, the diary and the letters touch on life in different sectors inside the camp at different periods of the war. Second, they include many details about the inmates' everyday lives, perceptions, and feelings in and about the most extreme space of persecution.

In the Holocaust historiography, there are several volumes about ghettos, ${ }^{4}$ camps, train journeys, and death marches ${ }^{5}$ that approach the subject from the perspective of space and experiences of space. The works dealing with the concentration camps focus on the structure and development of the camp system from the perspective of operators, organizers, and architectures. ${ }^{6}$ In comparison, relatively few studies focus on the social dimensions of the inmates' daily lives. ${ }^{7}$ However, the strategies used by the inmates were also influenced by the physical features of the camp. I argue that space-related experiences were key elements of everyday life in the camp, and perceptions, understandings, and uses of space were essential to survival in the camp.

By analyzing the deportees' texts from the perspective of attachment to place, which is a primary concept in environmental psychology, we can see how complex

2 Holländer, Lágerutarás, 180.

3 Csíkszentmihályi and Roschberg-Halton, The Meaning of Tbings, 59-60.

4 Cole, Holocaust City; Cole, Traces of the Holocaust.

5 Baltman, The Death Marches; Gigliotti, Train Journey; Gigliotti et al., "From the Camp to the Road."

6 Some examples: Wachsmann, KL: A History of the Nazi Concentration Camps; Megargee, Encyclopedia of Camps and Ghettos; Dwork and van Pelt, Auschwitz; Jaskot et al., "Visualizing the Archive Building"; Kelly Knowles et al., "Mapping the SS Concentration Camps."

7 Pingel, "Social Life in an Unsocial Environment," 71. 
this use of space and, in connection with this, the organization of everyday life was. Place attachment is considered "the bonding of people to places." ${ }^{8}$ We find signs of these attachments in the notes and drawings, which suggest that the prisoners reflected on their built and natural environments. The inner world and the closed society of Bergen-Belsen and the similar concentration camps and forced labor camps were shaped by the diversified systems of relations among individuals and groups. The prisoners, however, did not connect to other people only. Inevitably, they formed attachments to the places themselves, including the built and natural environment, the objects, sounds, noises, and even the weather. The physical environment created a certain emotional environment around the individual. What kind of bonds evolved between the spaces of the camp and the prisoner's emotions? How did the physical features and the symbolic meanings of the environment influence their way of thinking?

The personal stories which unfold in the ego-documents I examine in this article suggest that the prisoners should be viewed not simply as victims of SS terror, but also as actors. ${ }^{9}$ According to this broad assumption, the spaces of the camp could be characterized not simply as tools of repression in the hands of the SS, but also as spaces within which the prisoners had some (admittedly limited) opportunities to adapt. From this perspective, one can raise the question, how did the deportees use the spaces of the camp for their benefit? Were they free to use the spaces in various, even if limited ways? I search for answers to these questions in my discussion of Holländer's diary and Magda Székely's letters, but before presenting their stories, I offer a brief overview of the place where they were forced to spend some months in 1944-45.

\section{The Camp}

The implementation of the so-called Final Solution, i.e. the attempt to exterminate the Jews of Europe, can be examined as a spatial process. ${ }^{10}$ The persons concerned were deprived of their homes and new places were established for them, including ghettos, collection points, and labor, concentration, and extermination camps. The world of the camps was a completely new spatial

8 The theories and findings of environmental psychology can be used in Holocaust studies. Scannell and Gifford, "Defining place attachment."

9 Wachsmann, KL: A History of the Nazi Concentration Camps, 22; Prenninger, "The Camp Society," 39-40.

10 Some examples for edited volumes of the geographical approaches: Kelly-Knowles et al., Geographies of the Holocaust, Cole, Holocaust Landscapes; Giaccaria and Minca, Hitler's Geographies. 
experience for those who ended up there, something they had never seen before. $^{11}$

Bergen-Belsen was one of the largest Nazi concentration camps. ${ }^{12}$ This camp has a very complicated history and a special place in the web of Nazi camps because of its unusual mission. Bergen-Belsen functioned as a "residence camp" (Aufenthaltslager) from 1943, and this fact had a great impact on the history of the Hungarian Holocaust, too.

Having acquired Adolf Hitler's consent, in the spring of 1943 Heinrich Himmler ordered the establishment of a collection camp for Jews who might be used in prisoner exchanges or permitted to travel to neutral territory in return for money. He made clear that the conditions in this camp should be such that the Jewish prisoners "are healthy and remain alive." These "exchange Jews" were placed in the special sector of Bergen-Belsen, the Sonderlager. ${ }^{13}$

The passengers on the so-called "Kasztner train" from Budapest were housed in the Hungarian camp (Ungarnlager) inside the Sonderlager in the summer of 1944. They left the camp and arrived in Switzerland in August and in December 1944. Then a next transport came from Budapest with 2,001 people. Forced laborers were added to this group, Károly Székely among them, on December 14. The passengers in total $5821^{14}$ on these trains were placed in the Hungarian camp, where the conditions were better than in the other camps. Families were kept together, they weren't taken to do forced labor, and they were permitted to keep their luggage. ${ }^{15}$

In the summer of 1944, Bergen-Belsen went through a huge transformation. It went from a site for the "exchange of prisoners" to a reception camp for inmates from other camps, mainly sick forced laborers. ${ }^{16}$ Several transports brought inmates from Auschwitz (for example Margit Holländer) and other concentration camps. Thousands of Hungarian prisoners were placed in the barracks in the camp for normal prisoners (i.e. prisoners who were not treated

11 Cole, Holocaust City, 19-20.

12 See its summary in Shephard, After Daybreak, 18-26.

13 The Sonderlager had several separate parts where Polish, Dutch, Greece deportees and citizens from neutral countries were held. Wachsmann, KL: A History of the Nazi Concentration Camps, 345-50.

14 We have name lists about the inmates of the Ungarnlager but we do not know the exact number of inmates of the other camp sectors. The Gedenkstätte cumulative name database includes 15,423 people were deported from Hungary to Bergen-Belsen (on September 14, 2020). I thank Bernd Horstmann (Bergen-Belsen Memorial) for the data.

15 Kádár and Vági, Self-financing Genocide, 209-19.

16 Lattek, "Bergen-Belsen. From 'Privileged' Camp to Death Camp." 
differently by the camp authorities). The overwhelming majority was placed in the women's camp (Frauenlager) and a smaller number was put in the men's prison camp (Häftingslager).

As a result of the evacuation of the other camps because of the Soviet advancements, the population of the Bergen-Belsen grew from 15,000 to 44,000 by March 1945. In March, 18,000 people died of famine, hypothermia, sickness, and a typhus outbreak which had begun in February. According to the estimates, the death rates were highest in the women's camp, where Magda Székely became one of the victims of the epidemic. By the last months, the camp where the prisoners who were being held for potential exchange and therefore were being given somewhat better treatment also became a site of mass death. The Hungarian camp was evacuated only a few days before the arrival of the BritishCanadian Army, and the prisoners were liberated in Theresienstadt, Hillersleben (where Károly Székely was being held), and Tröbitz.

The Bergen-Belsen concentration camp was liberated on April 15, 1945, by the 8th Armored Division of the British Army. They were greeted by the sight of 53,000 emaciated prisoners and more than 10,000 corpses. Those who were liberated in Bergen were waiting for repatriation in the displaced persons (DP) camp established in the military camp. Holländer was one of them. ${ }^{17}$

The differences in the perspectives from which the personal stories are told are explained in part by the different statuses of the deported groups ("exchange Jews" and the ordinary prisoners). Margit Holländer was brought from Auschwitz to Bergen-Belsen in August 1944. She was transferred to Salzwedel to work in a factory in early October, where she was liberated in April 1945. Three months later, she was brought back to the DP camp which had been established in Bergen-Belsen in the meantime, from where she returned home in October. Károly Székely and Magda left Budapest in December 1944, but they did not arrive at Bergen-Belsen at the same time, and they were held in two different sectors of the camp, Károly in the Hungarian camp and Magda in the women's camp. The letters they exchanged were written between December 1944 and March 1945, when Károly was evacuated and Magda died.

17 The Wehrmacht/SS military stone barracks were a mile away from the barracks of the lager. The latter were destroyed in April and May of 1945 under the leadership of the British army. Schulze, "Forgetting and Remembering," 217-19. 


\section{Diary and Letters}

The story of Bergen-Belsen is mainly known from the narratives of its liberation. ${ }^{18}$ The secondary literature and the testimonies of the British-Canadian Army and the members of the medical teams offer impressions of the period (April 1945) when the history of Bergen-Belsen as a concentration camp came to an end, albeit the history of the site and the life stories of the inmates had not come to an end. The accounts of the people who suffered deportation, however, are conspicuously absent from the international (mostly English language) publications. ${ }^{19}$ This is particularly true in the case of the Hungarian Jews and political prisoners. ${ }^{20}$

Margit Holländer's diary ${ }^{21}$ includes five handwritten notebooks $10.5 \times 15 \mathrm{~cm}$. In addition to the manuscript, which comes to 97 pages, there is a typewritten transcription which was made in 1962 and which contains supplements. ${ }^{22}$ Holländer did not start her diary in Bergen-Belsen, but in Salzwedel in April 1945, and she continued writing entries in the DP camp in Bergen-Belsen. Thus, her notes about the time before the liberation are technically not referred to as a diary but rather as a recollection. Some diaries survived from the Hungarian camp, where the conditions were much better from the perspective of an inmate's ability to keep a written record of the events, as I mentioned above. ${ }^{23}$ In comparison, similar sources from the prisoners' camps (i.e. sources that were written at the time and not decades later) are very rare. As far as I know, only two

18 For instance, Shephard, After Daybreak; Celinscak, Distance from the Belsen Heap; Bardgett and Cesarani, Belsen 1945; Reilly, Belsen. Testimonies: Flanagan and Bloxham, Remembering Belsen; Berney and Wood, Liberating Belsen Concentration Camp; Hargrave, Bergen-Belsen 1945; Hardman and Goodman, The Survivors.

19 Some example of translations of testimonies by authors from other European countries: Laqueur, Diary of Bergen-Belsen; Reichental and Pierce, I was a Boy in Belsen; Herzberg, Between Two Streams; Lévy-Hass, Diary of Bergen Belsen.

20 Only a few Hungarians' testimonies have been published in English, for example three memoirs: Perl, I was a doctor in Auschwit;; Lantos, Parallel Lines; Stadler, Mosaics of a Nightmare; and a collection of drawings: Abadi, Elmondom ... my story...1942-1945.

21 The original diary is in the possession of the author's daughter, a copy can be found in the Holocaust Memorial Center, and it was published in 2017 by Jaffa Publishing Company. Holländer, Lágerutazás.

22 The publication released includes the diary, but it is distinctly separated from this text, and also where we considered it reasonable, we inserted supplementary parts from the typewritten transcription. When we quoted from the latter in the text, we indicated this with italics in all cases. This is true for parts quoted here too.

23 In the different collections and at private owners, I found six diaries, those were written by authors from the Hungarian camp. 
texts were written by Hungarian deportees in the prisoners' camp and based on original diary notes, or at least only two survived. ${ }^{24}$

This mixed genre, which includes reminiscence and contemporary notes, is very typical among the personal sources. The survivors got their hands on paper and pencils after or around the liberation and started to record their time in the ghetto and the camp. At one point, the memoir turns into a diary because the story catches to the moment of writing.

Holländer wrote her notes at a time when she was quite close to the events of summer and autumn 1944. Moreover, the inmates in the Hungarian camp, including the authors of the diaries, were mainly intellectuals and members of higher social strata. Holländer came from a poor peasant family. Before she was deported, she had been working as a factory laborer and, later, a maid. Thus, she had a different background and point of view compared to the perspective of the diary writers from the Hungarian camp.

Her diary is also interesting because it includes 39 drawings, floor plans, and maps of the camps. She made drawings of places which were significant for her for some reason, inducing both positive and negative associations: the Auschwitz bathhouse, the Salzwedel barracks, the environment of the DP Camp, and the route of the funeral procession after the liberation. These drawings could not be called maps. They are neither accurate enough nor precise enough from the perspective of scale to enable someone to identify the locations, so the term befitting them is a "mental layout plan."

Magda Székely's letters are also a rare surviving source. While there are numerous indications of communication and letter writing inside the camp in testimonies, the letters themselves were not saved. So far, I have found only one other example of a letter that was sent by a Hungarian prisoner inside the camp. ${ }^{25}$ In comparison, the Székely bequest includes 14 letters. ${ }^{26}$ The messages, which were written on shapeless pieces of paper and sent between the two barracks between December 1944 and March 1945, put the authors at serious risk since they would have been killed had the letters been discovered. Magda Székely died, so only the letters her father wrote have survived, as they were saved by him.

24 The diary of Sándor Zinner, Holocaust Memorial Center, 2011.169.1-4; The diary of Gabriella Trebits, Bergen-Belsen Memorial, BO 41731.

25 Magda Reichfeld's letter, Bergen-Belsen, Autumn 1944. Memorial Museum of Hungarian Speaking Jewry (Safed) C.2208. (I read a copy of the letter in the Archive of the Bergen-Belsen Memorial, BA 1012.) A Dutch example of letter writing in the camp: Polak and Soep, Steal a pencil for me.

26 Károly Székely's bequest ended up in the collections of the Holocaust Memorial Center in April 2013 thanks to Zsuzsanna Székely through donation, published in 2014: Huhák and Szécsényi, Táborok tïkrében. 
The letters are, in part, about the women's camp and, in particular, about how it was connected to the Hungarian camp. None of the prisoners knew both camps from the perspective of the prisoner, but these letters refer in a certain way both of them.

The diary and the letters represent the history of the camp from unique perspectives. Furthermore, the texts are related to the different sectors of the camp and cover different periods, so they further a more subtle understanding of the complicated history of the camp.

\section{The Story of Margit Holländer}

"March 6, 1942, is a day that I will never forget. It was the day I came to Újpest, not even thinking about how far I will go from my home village." The first entry in the diary reports a change of location. At the time, Újpest, a workingclass neighborhood close to Budapest (since 1950 part of Budapest), was still a faraway land for a girl growing up in a little village Doboz in southeastern Hungary. Three years later, in October 1945, during her homecoming journey of 1,000 kilometers from Bergen-Belsen, Holländer presumably thought differently about distances.

The 18-year-old Holländer was deported from the ghetto in Újpest in June 1944. ${ }^{27}$ She was taken to three different concentration or extermination camps, though this meant being held in a total of five different camps, as the functions of the individual sites changed: Auschwitz (camp B III), Bergen-Belsen (the women's camp), the Salzwedel forced labor camp, the transit camp for people who had been liberated in the same location, and, finally, the Bergen-Belsen DP Camp.

The journey is an important part of the Holocaust narrative. It is related to the loss of home, and the physical circumstances of traveling. This is true of Holländer's diary. From a practical perspective, the conditions of the terrain over which the prisoners were forced to move on foot between or inside the camps were not irrelevant. When Holländer was punished, she had to kneel on the ground of Lagerstrasse, which was covered with sharp stones, but it was not easy to walk on the ground either, as the small stones injured her feet. ${ }^{28}$

27 On the ghettos in rural parts of Hungary (meaning outside of Budapest): Cole, Traces of the Holocaust, Fritz and Novak-Rainer, "Inside the Ghetto."

28 Definitions of sense of place have a three-component view which weaves together the physical environment, human behaviors, and social and/or psychological processes. However, the role of the physical environment is often neglected. Stedman, "Is it really just a social construction?" 
Open spaces such as Lagerstrasse and the Appellplatz easily became sites of dangers compared to the shelter of the dark and crowded barracks. ${ }^{29}$ Prisoners were often beaten, and the guards would hit them with sticks when they did not walk fast enough or if the guards felt that they were in the way. As Holländer notes in one of her entries, they struck her during one of the marches. Her feet were size 37 (US 6.5), but she was given a pair of men's boots that were so big that she was unable to walk in them at a normal pace. ${ }^{30}$

The road is mentioned in different entries. Holländer was at the same sites first as a prisoner, later as a free woman in the DP Camp, and then as a mourner commemorating her dead companions. Her account suggests that, as she revived memories of people walking down Lagerstrasse in September 1945, the different experiential layers of the timelines and the journey piled one on top of the other:

\begin{abstract}
A little girl came half an hour later, saying that there will be a headstone unveiling in the death camp. Boriska and I went there. On the same road on which we had been walking exactly a year ago on this day. We met three Jewish boys on the way. One of them told us that he had been brought here a few days before the liberation, the whole road was full of trees and electric lines. The over-exhausted people had to get through these obstacles. If any of them dropped to the ground, they were taken into the woods. They heard a shot and it was over. ${ }^{31}$
\end{abstract}

Holländer's entries and drawings also describe or depict the buildings in the camp. One of the drawings is of the Auschwitz bathhouse, the Brezinska. ${ }^{32}$ The notes describe the devices in the rooms (clothes racks, partition grilles, windows, furnaces), their functions, i.e. what was happening in the given space ("the depilated body parts were anointed with some acrid fluid"; "we had to put on the clothes while walking in front of the men"; "they painted an X on our backs with yellow oil paint"), and where the men were standing compared to the girls who were going along the route marked by arrows.

The women, who had not had a bath for two weeks at the time, saw the clothes racks in the first room as accessories of the civilized and cultured process

29 Many places in the camp were dangerous for the inmates because they were not aware of the design and the geographical features, and the SS used this knowledge against them. Jaskot et al., "Visualizing the Archive Building," 185.

30 Holländer, Lágerutazás, 61.

31 Ibid., 116.

32 Ibid., Figure annex no. 6. 
of undressing. However, the huge windows in the hallway did give them any light. Rather, they let in the cold and the wind. The most significant aspect of this space, however, was the clothes and the process itself of being forced to undress, having one's clothes taken from one, and being given prison clothes. ${ }^{33}$ The depiction of the hallway leading from the undressing room is long in the drawings. It may indeed have been long, but the distance between the two rooms on Holländer's mental map may have been increased by the feeling of humiliation caused by the fact that she was forced to march naked in front of men. ${ }^{34}$ Thus the clothes and the site itself (the disinfection building) were associated with the ritual and the emotional process and impact of becoming a prisoner.

Holländer's feelings regarding the Bergen pine forest are more complex. ${ }^{35}$ Emotional attachment to place is a complex phenomenon. Holländer's diary entries offer accounts of three different experiences regarding the trees which are related to three different times and different states of mind. Upon arrival, the sight of the pine forest created a bad feeling inside her due to a fear of the unknown:

\begin{abstract}
We are walking down the road in rows of five with armed SS soldiers with dogs on either side. There are woods are either side, and it's getting darker and darker. The leaves on the trees are moving, and you can see strange mounds and holes among the trees. Everyone is overwhelmed with bad presentiments, such a fearful sight this forest was. I started seeing graves in my mind. I was getting really scared. This is death, I thought to myself. They will execute us right here. ${ }^{36}$
\end{abstract}

Somewhat later, when she considered her situation more tolerable (compared to Auschwitz), the pine trees intensified Holländer's desire for freedom while she was in a state of apathy. After she had survived the first encounter with the forest, nature no longer seemed to symbolize death to her, but rather came to embody freedom which was the opposite of the built environment of the camp:

33 Belk, "Attachment to Possessions," 51-54. The psychological importance of one's own clothes was proved when the inmates were brought to select dresses for themselves in the clothing store after the liberation. As the women received clothes, their social personalities would return. Shephard, After Daybreak, 99.

34 "My Goodness, how awful it was walking naked in front of the men, they were watching us like we were stave woods. As we were proceeding slowly, we arrived at a long, narrow hallway. Some part of it was separated with a metal grid. I saw some kind of furnace there, and men in striped clothes, who were busy working on some garments." Holländer, Lágerutazás, 36.

35 She even glued a tiny leafy branch from the forest into one of her booklets as a memory.

36 Holländer, Lágerutazás, 57. 
We were heading back to the lager. The road goes through the forest, our grievous procession was marching while we were surrounded by armed men. There was a nice smell of pines among the trees standing in line along the road. I was overwhelmed by the desire if only I could walk alone freely once again! ${ }^{37}$

Entries written after the liberation of the camp contain descriptions of the forest which present it as a picturesque landscape. No longer the backdrop for scenes dominated by the fear of or a symbol of freedom, the pine forest finally turned into what it would have been without the lager: it appeared as a pleasant natural environment at the edge of a populated area.

I love wandering around together with Manci. There are so many beautiful landscapes and nice forest trails in the camp. It is vast. The camp is like a city at the edge of the forest. Especially in the evening, when the lights are lit along the fine asphalted roads. ${ }^{38}$

The drawings in her diary show the areas of the camp with which she was familiar at the given time. After liberation, when she was given the freedom to move around at will, the horizon grew. The windows became one of the central places of daily life in the DP camp because they opened onto the noises of the "street" and offered views of the neighboring barracks and social life outside. The diary entries written at this time suggest that it was a period filled with relatively positive emotions. The former prisoners were able to socialize with one another freely. The young women and girls joked while sitting on the window sills, and Italian and Russian prisoners of war and British and Hungarian soldiers came over to chat with them and court them: "We were under a real Italian invasion." 39 Although the diary suggests that the women and girls sometimes enjoyed the attention that they were paid by the men, some entries also suggest that they did not want to let everybody get close to them and that the autonomy over the spaces even entailed shutting out certain groups:

We have a habitual place where we go near the stables, that's where Manci and I usually go. We sit there for hours. One day, there was a German nurse and a German Red Cross soldier at the place, so we 
wrote a note and nailed it to the tree with the following text: Ferbotn Dautcsh Fherflhuhte. Kaput Hitler. ${ }^{40}$

Holländer indicated the location of the episode in one of her drawings, and she did a drawing of the sign. ${ }^{41}$

However, these descriptions of vivacious social life touched only on the surface of life in the DP camp. In addition to the challenges of physical recovery, almost all of the inmates were grappling with mental and psychological traumas. ${ }^{42}$ The physical and mental burdens which were endured by members of the Jewish families who were deported had begun, in many cases, before the deportations. The story of Károly and Magda Székely takes us back to Budapest in 1944, to the events which resulted in the letters written by Magda several months later in Bergen-Belsen.

\section{The Székely-family}

Károly Székely (1898-1965) grew up in a lower-middle-class Jewish family in Budapest. He earned a living as a chemist-perfumer. He lived together with his wife Katalin Stern, their daughter Zsuzsanna (born in 1943), and Magda, who had been born in 1921 from his first marriage. Rózsi Günsz, Zsuzsanna's nanny, was also part of the smaller family. They lived in Király Street, in the seventh district of Budapest, which was known as the traditional "Jewish quarter" of the city.

The first shock to their family life was the conscription of the head of the family into the labor service in $1942 .{ }^{43}$ Beginning in the spring of 1944, the women in the family went through the stages of discrimination against Jews in Budapest. In the summer of 1944, Károly Székely served in a forced labor service camp in the capital, separated from his family. In June, Katalin and the others were relocated to a so-called Yellow Star building. ${ }^{44}$ Until the Arrow Cross Party took power, however, they were not in any immediate danger of death. On a winter's day, they were all taken to the bank of the Danube, where the paths

40 The correct spelling of the text in German would be: "Verboten Deutsch Verfluchte. Kaputt Hitler." It means: Prohibited for damned Germans. Hitler is dead. Holländer, Lágerutazás, 102.

41 The diary of Margit Holländer, 4th booklet.

42 Shephard, After Daybreak, 108-12.

43 Hungarian Jewish men were conscripted into the unarmed labor service (munkaszolgálat) in Hungary. Csősz, "The Origins of Military Labor Service in Hungary."

44 Instead of establishing a centralized ghetto, the authorities in Hungary created so-called Yellow Star buildings for Jewish citizens in Budapest. 
of women's lives parted. Katalin and Zsuzsanna were taken out of the queue by a "more humane" Arrow Cross member (or a Zionist rescuer in disguise), who released them and warned them to "get lost quickly." 45 However, until the liberation of the city by the Red Army, they had to struggle with the inhumane conditions in the Pest ghetto. Magda and Rózsi, however, were not as fortunate. They were expecting to be shot into the river with the members of the group lined up on the pavement of the riverbank. All we know for sure is that the Arrow Cross members, who were often acting on ad-hoc decisions, forced them to do work removing rubble in parts of the city that had been bombed. ${ }^{46}$

A new twist in their story occurred when, in December 1944, Károly, Magda, and Rózsi were deported to Bergen-Belsen, though not at precisely the same time. Károly was taken to the Hungarian camp as a member of the so-called protected forced labor unit. ${ }^{47}$ Magda and Rozsi were put in the women's camp, so they essentially ended up in very different living conditions, but Károly and Magda found each other again.

The tools used for written communication, i.e. the paper and the pencils, came from the Hungarian camp, and that is how they ended up in the system of information exchange and news circulation within the women's camp. The messengers were probably people who brought food or other prisoners with functions which enabled them to move more freely between the different parts of the camp. Since clothes and foods were changing hands not only on the camp market ${ }^{48}$ but occasionally between the correspondents as well, the letters can also be considered as a report on objects migration within the camp. Magda mentions socks and bread as concrete items, and she even managed somehow to get her hands on some cigarettes, which were like currency in the camp. The prisoners were given cigarettes in the Hungarian camp for a while, which were, in a way, more valuable for non-smokers, as they could more easily exchange the cigarettes for other items than people who craved tobacco. The father was a

45 Zsuzsanna Székely, interview by Heléna Huhák and András Szécsényi, April 1, 2014, Budapest, Hungary.

46 On the story of Hungarian Jews in Budapest in 1944: Cole, Holocaust City; Vági et al., The Holocaust in Hungary.

47 Protected Labor Service companies whose members were under the diplomatic protection of a foreign country in 1944-45.

48 Each concentration camp had its own underground economy. On the black markets, bread, shoes, cigarettes, pins, thread, and many other things changed hands. Wachsmann, KL: A History of the Nazi Concentration Camps, 394-97. 
heavy smoker, but he did without cigarettes, getting them instead to Magda and Rózsi in order to enable them to trade them for clothes and food.

The letters report on failed and successful attempts to meet and seem mostly intended to soothe Károly. Movement within the camp was adapted to the expected meetings by the fence, and thus, the spot by the fence had a central role in the daily lives of the Károly and Magda. Károly had more freedom to move around due to the internal autonomy of the Hungarian camp, and the girls were also able to move some, as they had to do forced labor in their part of the camp only occasionally. By late 1944, the camp had become so crowded that it became easier for Károly and Magda to meet, and they were less likely to get caught.

Attachment to place is not always positive. Some research emphasizes the plurality of emotional bonds to places, bonds which include negative feelings as well as positive. ${ }^{49}$ Despite the harsh and inhumane conditions in the camps, prisoners still developed attachments to some specific sites. ${ }^{50}$ Since the Holocaust involved the displacement and murder of individuals and the destruction of communities, one might well assume that the only emotional attachments which were formed to the spaces within the camps were attachments involving abstraction, separation, and apathy. However, in the case of Magda, optimism, the will to live, and mental integrity have also created "positive places." The meetings among Károly and Magda created a "positive place" in a negative environment. This was possible in this hostile place, where inmates were deprived of freedom and rights because place attachment behaviors are not necessarily territorial. Territoriality is based on ownership and control of space, but attachment to places is an affective, proximity-maintaining bond that can be expressed without the underlying purpose of control. ${ }^{51}$

The meetings by the fence had an undoubtedly enormous emotional resonance for Károly and Magda. This site came to embody the hope each must have cherished to see the other again. The quarantine meant increased restrictions on movement and thus effectively eliminated the "positive places" within the camp. Magda wrote about the quarantine on February 28:

49 "The places where Nazi lagers were located are certainly 'places' with a strong emotive value, in particular for Jewish people. Would they say that they are 'attached' to them?" Guiliani and Feldman, "Place attachment in a developmental and cultural context," 272.

50 Some inmates accounted that they got some calmness when they sat down by the wall of the barrack and enjoyed the sunshine; others often visited those places where they met their acquaintances earlier.

51 Scannell and Gifford, "Defining place attachment," 4. 
Unfortunately, we can't leave this place at all for a while. This is a socalled quarantine barrack. I do not know why they brought us here, because t. [thank] God, we are fine. I would love to fly into your arms, but there is a gate here with a German guard, no one can leave this place, not even for work. I don't know how long it will last. ${ }^{52}$

The thoughts were written with few words but with much more emotional resonance. Positive exaggeration is frequent means: "Our appetite is great, we eat everything"; "The hot water was marvelous"; "The air is great"; "The sock is wonderfully warm." Besides love and her desire for her father, gratitude is the most common feeling the sentences refer to; every letter has a "thank God" phrase. ${ }^{53}$

Regarding liberation, Magda often refers to their hopes that her father will go and rescue them from the barrack. The vision of freedom becoming a reality was linked to a vision of Károly as a savior figure:

We think about you a lot, about going home as soon as possible. This keeps us going. When the moment comes, please, I want you to come for us, because that is a lot safer. We are waiting for you like the Jewish people for the Messiah. ${ }^{54}$

Due to the specificity of the situation in Bergen-Belsen, the euphemistic exaggerations and expressions of gratitude and the appreciation in Magda's letters may not have been entirely sincere. Rather, they may have been intended to provide some comfort for her father, who Magda must have thought undoubtedly feared for his daughter's wellbeing (and life). She may also have feared that he felt helpless, and she may have sought to assuage this fear. Károly indeed may have felt a terrible sense of helplessness, given the divided world of Bergen-Belsen, which consisted of different spaces that provided fundamentally different opportunities for survival. People in the Hungarian camp were aware of the conditions in the prison camp. György Bognár, who was held in the same barrack as Székely, wrote the following: "K[ároly] Sz [ékely] is talking about his family. Everyone is crying at such times, I was crying too. My daughter, he says, we left Teleki Square together and now she is in the other camp. They are treating her worse than me, why are they treating her differently? And then he

52 Huhák and Szécsényi, Táborok tükrében, 93-94.

53 Ibid., 85-86.

54 Ibid., 93-94. 
begins weeping and crying." 55 However, the existence of the Hungarian camp also made it possible for Károly to provide some support for Magda and Rózsi, who, as young women, could have even survived the adversities with the clothes, foods, and cigarettes (which they could use to trade for more food and clothes) that they received from Károly if the typhus outbreak hadn't claimed their lives. ${ }^{56}$

Magda's last letter, written March 5, seems full of desperation and fear. Though at the beginning of the letter she writes, "thank God we are fine" (perhaps in an effort to comfort her father), she then offers an account which seems dire:

Rózsi is dying. The last minutes. Daddy, only you can help us. I don't know what will happen. There's an epidemic too. My feet are swollen, I can barely walk. We can't drink any water here, but we are always thirsty. This is terrible. I say your name at night, can't you hear it? Daddy, help me! I am waiting for you in terrible desperation. Hugs and kisses from Muki [a pet name for Magda]. ${ }^{57}$

In spring 1945, father and daughter were separated again. Károly Székely was taken from Bergen-Belsen on the occasion of the evacuation on April 7. After the liberation, he traveled from the DP camp in Hillersleben to BergenBelsen in the hopes of finding Magda, but he did not know anything about her whereabouts. He found his wife, their daughter Zsuzsanna, and his mother-inlaw unhurt in Budapest in June. However, regarding the fate of Magda, months of uncertainty followed for the Székely family. Finally, in 1946, they received the official announcement of her death by the International Red Cross. ${ }^{58}$

\section{Conclusion}

According to Edward W. Soja, "thirdspace" is the combination of the physical world around us and our conceptions of and thoughts about this physical world. The third, lived space is the reality experienced by the subjective consciousness "here and now," in the given moment. These three spaces are closely connected

55 The diary of György Bognár. Holocaust Memorial Center, 2011.25.1. 88-89. Péter Lantos and other inmates of the Ungarnlager wrote about the wrong conditions is in the other camp sectors. (Further examples: Huhák, "Bergen-Belsen a deportált magyar zsidók élettörténeteiben," 243-95.)

56 The typhus epidemic was spread by lice, which were spread with the exchange of goods in the camp, mostly clothes, and also among prisoners via contact and on the camp black market.

57 Huhák and Szécsényi, Táborok tükrében, 95-96.

58 Székely interview. 
to and mutually affect one another. Every space is physical, imagined, and lived at the same time. ${ }^{59}$ In the personal sources, Bergen-Belsen figures as a "thirdspace." The environment meant the physical setting and the symbolic meanings of this setting in Margit Holländer's diary. We can see that the bath and the process of being compelled to strip were physically and mentally difficult for her. Later, a few basic accouterments of normal life, such as a table and chairs, made her more hopeful. Finally, in the DP Camp, the window of their flat served as a backdrop for her acquaintanceship with the young Russian and Italian prisoners of war and had a strong psychological effect on girls and boys companies. ${ }^{60}$

Though one may have an understanding of the camps as isolated built areas, the natural environment also figures in Holocaust stories. In testimonies, "nature functioned both materially and imaginatively during the Holocaust." ${ }^{61}$ Men and women developed emotional attachments to the plants and weather. One recurring motif in the testimonies is referenced to nature as the last thing that the Germans did not take from the prisoners. One of Margit Holländer's drawings captures this. The drawing is of the prisoners standing on the Appellplatr, but it includes the sun shining down on them. ${ }^{62}$

Holländer also mentioned in her entries how her feelings about the natural environment changed according to the situation. In the extremity of the deportation, the forest was a source of potential danger. ${ }^{63}$ In the normal, safe situation it was the place of relaxing and enjoyment. What happened in the built environment, between the fences, on the camp roads, on the Appellplat, and in the barracks meant the reference point of her feelings about the natural environment. Emotional attachments to the spaces in the camp (sectors of the camp and the fence between them) are also a key element of the Székely-letters. These texts draw our attention to the emotion-filled points of the space. Some of the spaces were sites of trauma, but others had positive associations, such as the barbed wire fence where Károly and Magda saw each other.

The coincidence of one member of a family being incarcerated in the prisoner's camp and another in the Hungarian camp was not rare. There are hints of this in other testimonies, though with very few details. Magda Székely's

59 Soja, Thirdspace, 53-82.

60 We find numerous stories about this in the accounts of the liberators and members of the medical team, too. One example: Shephard, After Daybreak, 111.

61 About the complex connection between the Jews and the forest see: Cole, "Nature Was Helping Us."

62 Holländer, Lágerutazás, Figure annex no. 5.

63 Cole, "Nature Was Helping Us." 
letters show how difficult this separation was for the two people who were related, mainly for a father who knew that his daughter was being held under worse conditions on the other side of the camp. The separation of the physical spaces of the camp (due to the special status of Bergen-Belsen) determined the emotional bonds between the father and the daughter.

The illegal world of the camp, the secret letter writing, meetings at the "positive places," and the exchange of goods on the black market are evidence of prisoners' capacity and room for maneuvering. However, the camp inmates' opportunity was very limited compared to the power of the SS. This depended on the circumstances and the physical environment every time. The open camp road could become a site of danger because of SS aggression, but at other times, it could be a site where prisoners had an opportunity to talk and meet. The meanings of the spaces of the camp and its surroundings changed after the liberation when for Margit Holländer the forest became a place with positive associations and she dared post an announcement banning Germans from going to their favorite spot. However, the Magda Székely's letters make clear that the use of space was still limited. Károly was not able to change his daughter's circumstances meaningfully, and while he had advantages as a prisoner who was being held in the Hungarian camp, these minimal advantages did not enable him to save his daughter.

\section{Bibliograpby}

Primary sources

Holokauszt Emlékközpont [Holocaust Memorial Center]

2011.555.1. The diary of Margit Holländer

2011.25.1. The diary of György Bognár

2011.169.1-4. The diary of Sándor Zinner

Gedenkstätte Bergen-Belsen [Bergen-Belsen Memorial]

BO 4173 1. The diary of Gabriella Trebits

Memorial Museum of Hungarian Speaking Jewry (Safed)

C.2208. Magda Reichfeld's letter, Bergen-Belsen, Autumn 1944

Zsuzsanna Székely, interview by Heléna Huhák and András Szécsényi, April 1, 2014, Budapest, Hungary. (In the possession of the interviewers)

Abadi, Ervin. Elmondom ... my story... 1942-1945. Budapest, 1974.

Berney, Leonard, and John Wood. Liberating Belsen Concentration Camp: a Personal Account. Leonard Berney, Middletown, 2015. 
Flanagan, Ben, and Donald Bloxham, eds. Remembering Belsen: Eyewitnesses Record the Liberation. Portland, OR: Vallentine Mitchell, 2005.

Hanna Lévy-Hass. Diary of Bergen Belsen: the Story of How One Woman Survived the Holocaust. Chicago, Ill.: Haymarket, 2007.

Hardman, Leslie H., and Cecily Goodman. The Survivors: The Story of the Belsen Remnant. London: Vallentine, Mitchell, 1958.

Hargrave, Michael John. Bergen-Belsen 1945: A Medical Student's Diary. London: Imperial College Press, 2013.

Herzberg, Abel J. Between Two Streams: a Diary from Bergen-Belsen. London: Tauris Parke Paperbacks, 2008.

Holländer, Margit. Lágerutazás: Holländer Margit feljegyzései a vészłorszakeról és az újrakezdésról (1945-1946) [Lager journey: Margit Holländer's notes on the Holocaust and starting anew, 1945-1946], edited by Heléna Huhák, and András Szécsényi. Budapest: Jaffa, 2017.

Huhák, Heléna, and András Szécsényi. Táborok tükéében: A Székely-család levelei a munkaszolgálat és a deportálás idejéböl [As seen from the camps: The letters of the Székely family from the time of forced labor and deportation]. Budapest: HDKE, 2014.

Lantos, Péter. Parallel Lines: a Journey from Childhood to Belsen. London: Arcadia Books, 2013.

Laqueur, Renate. Diary of Bergen-Belsen: March 1944-April 1945. Hannover, 1999.

Perl, Gisella. I was a doctor in Auschwitz. New York: International Universities Press, [1948]

Polak, Jaap, and Ina Soep. Steal a Pencil for Me: Love Letters from Camp Bergen-Belsen, Westerbork. Scarsdale: Lion Books, 2000.

Reichental, Tomi, and Nicola Pierce: I was a Boy in Belsen, Dublin: O’Brien Press, 2016.

Stadler, Aranka. Mosaics of a Nightmare. 1995.

Secondary literature

Blatman, Daniel. The Death Marches: The Final Phase of Nazi Genocide. CambridgeMassachusetts-London: The Belknap Press of Harvard University Press, 2011. doi: $10.2307 /$ j.ctvjnrvg1.

Belk, Russel, W. "Attachment to Possessions." In Place Attachment, edited by Irwin Altman and Setha M. Low, 38-62. New York-London: Plenum Press, 1992. doi:10.1007/978-1-4684-8753-4_3.

Celinscak, Mark. Distance from the Belsen Heap: Allied Forces and the Liberation of a Nazi Concentration Camp. Toronto: University of Toronto Press, 2015. doi:10.3138/9781442668775. 
Cole, Tim. Holocaust City. The Making of a Jewish Ghetto. New York: Routledge, 2003. doi:10.4324/9780203951255.

Cole, Tim. Holocaust Landscapes. London-Oxford-New York [etc.]: Bloomsbury, 2016.

Cole, Tim. "Nature Was Helping Us": Forests, Trees, and Environmental Histories of the Holocaust. Environmental History 19, no. 4 (2014): 665-86. doi:10.1093/envhis/ emu068.

Cole, Tim. Traces of the Holocaust. Journeying in and out of the Ghettos. London-New York: Continuum, 2011.

Csíkszentmihályi, Mihály, and Eugene Roschberg-Halton. The Meaning of Things: Domestic Symbols and the Self. Cambridge: Cambridge University Press, 2002. doi:10.2307/2067526.

Csősz, László. “The Origins of Military Labor Service in Hungary.” In The Holocaust in Hungary: Seventy Years Later, edited by Randolph, L Braham, and András Kovács, 75-104. Budapest-New York: CEU Press, 2016.

Dwork, Debórah, and Robert Jan van Pelt. Auschwitz: 1270 to the Present. New York: Norton; 2002.

Fritz, Regina, and Catherine Novak-Rainer. "Inside the Ghetto: Everyday Life in Hungarian Ghettos.” The Hungarian Historical Review 4, no. 3 (2015): 606-39.

Frojimovics, Kinga, and Éva Kovács. “Jews in a 'Judenrein' City: Hungarian Jewish Slave Laborers in Vienna (1944-1945)." The Hungarian Historical Review 4, no. 3 (2015): 705-36.

Giaccaria, Paulo, and Claudio Minca, eds. Hitler's Geographies: The Spatialities of the Third Reich. Chicago-London: The University of Chicago Press. 2016. doi: 10.1016/j. jhg.2016.08.008.

Gigliotti, Simone, Marc J. Masurovsky, and Erik B. Steiner. "From the Camp to the Road. Representing the Evacuations from Auschwitz, January 1945." In Geographies of the Holocaust, edited by Kelly-Knowles, Anne, Tim Cole, and Alberto Giordano, 192-226. Bloomington: Indiana University Press, 2014.

Gigliotti, Simone. The Train Journey: Transit, Captivity, and Witnessing in the Holocaust. London: Berghahn Books, 2009. doi:10.2307/j.ctt9qd53n.

Guiliani, M. V., and R. Feldman. "Place attachment in a developmental and cultural context." Journal of Environmental Psychology 13 (1993): 267-74. doi:10.1016/S02724944(05)80179-3.

Huhák, Heléna. “Bergen-Belsen a deportált magyar zsidók élettörténeteiben: A túlélők elbeszéléseinek helyközpontú vizsgálata" [Bergen-Belsen in the life stories of the Hungarian Jewish deportees: The place-centered examination of the survivors' 
narratives]. In Tanulmányok a holokaus:tról IX [Studieds on the Holocaust IX], edited by Randolph L. Braham, 243-95. Budapest: Múlt és Jövő, 2018.

Jaskot, Paul B., Anne Kelly Knowles, Chester Harvey, and Benjamin Perry Blackshear. "Visualizing the Archive Building at Auschwitz as a Geographic Problem." In Geography of the Holocaust, edited by Anne Kelly Knowles, Tim Cole, and Alberto Giordano, 158-91. Bloomington: Indiana University Press, 2014.

Kádár, Gábor, and Zoltán Vági. Self-financing Genocide: the Gold Train, the Becher Case and the Wealth of Hungarian Jews. Translated by Enikő Koncz, Jim Tucker, and András Kádár. Budapest: CEU Press, 2001.

Kelly Knowles, Anne, Paul B. Jaskot, Benjamin Perry Blackshear, Michael De Groot, and Alexander Yule. "Mapping the SS Concentration Camps." In Geographies of the Holocaust, edited by Anne Kelly-Knowles, Tim Cole, and Alberto Giordano, 18-50. Bloomington: Indiana University Press, 2014.

Kelly-Knowles, Anne, Tim Cole, and Alberto Giordano, eds. Geographies of the Holocaust. Bloomington: Indiana University Press, 2014.

Lattek, Christine. "Bergen-Belsen: From 'Privileged' Camp to Death Camp." In Belsen in History and Memory, edited by Jo Reilly, David Cesarani, Tony Kushner, and Colin Richmond, 37-71. London: Frank Cass, 1997.

Megargee, G. P., ed. The United States Holocaust Memorial Museum Encyclopedia of Camps and Ghettos, 1933-1945. Bloomington-Washington: Indiana University Press and USHMM, 2009.

Pingel, Falk. "Social Life in an Unsocial Environment: The Inmates' Struggle for Survival." In Concentration Camps in Nazi Germany: The New Histories, edited by Jane Caplan, and Nikolaus Wachsmann, 58-81. London-New York: Routledge, 2009.

Prenninger, Alexander. "The Camp Society: Approaches to Social Structure and Ordinary Life in Nazi Concentration Camps." In Interpreting in Nazi Concentration Camps, edited by Michaela Wolf, 25-42. New York-London-Oxford-New DelhiSydney: Bloomsbury Academic, 2016.

Reilly, Joanne. Belsen: The Liberation of a Concentration Camp. London-New York: Rutledge, 1998.

Scannell, Leila, and Robert Gifford. "Defining place attachment: A tripartite organizing framework." Journal of Environmental Psychology 30 (2010): 1-10. doi:10.1016/j. jenvp.2009.09.006.

Schulze, Rainer. "Forgetting and Remembering: Memories and Memorialisation of Bergen-Belsen.” In Belsen 1945: New Historical Perspectives, edited by Suzanne Bardgett, and David Cesarani, 217-35. London: Portland, OR: V. Mitchell published in association with the Imperial War Museum, 2006. 
Shephard, Ben. After Daybreak: The Liberation of Bergen-Belsen. London: Jonathan Cape, 2005.

Soja, Edward W. Thirdspace: Journeys to Los Angeles and Other Real-and-Imagined Places. Cambridge: Blackwell, 1996.

Vági, Zoltán, László Csősz, and Gábor Kádár. The Holocaust in Hungary: Evolution of a Genocide. Lanham: AltaMira Press, 2013.

Wachsmann, Nikolaus. KL: A History of the Nazi Concentration Camps. New York: Farrar, Straus and Giroux, 2015. 